\title{
Enteroparasites in Riverside Settlements in the Pantanal Wetlands Ecosystem
}

\author{
Patrícia Vieira da Silva $\left(D,{ }^{1}\right.$ Lucimare dos Santos Maciel, ${ }^{1}$ \\ Ludiele Souza Castro $\mathbb{D}^{1},{ }^{1}$ Paula Guerra Murat, ${ }^{1}$ Minoru German Higa Junior, ${ }^{1}$ \\ Patrícia Honorato Zerlotti, ${ }^{2}$ Ana Rita Coimbra Motta-Castro, ${ }^{1}$ \\ Elenir Rose Jardim Cury Pontes, ${ }^{1}$ and Maria Elizabeth Cavalheiros Dorval ${ }^{1}{ }^{1}$ \\ ${ }^{1}$ Postgraduate Program in Infectious and Parasitic Diseases, Universidade Federal de Mato Grosso do Sul, Campo Grande, MS, Brazil \\ ${ }^{2}$ Ecologia e Ação (ECOA), Campo Grande, MS, Brazil \\ Correspondence should be addressed to Maria Elizabeth Cavalheiros Dorval; mecdorval@gmail.com
}

Received 5 May 2017; Revised 24 November 2017; Accepted 28 November 2017; Published 16 January 2018

Academic Editor: Kwang Poo Chang

Copyright (C) 2018 Patrícia Vieira da Silva et al. This is an open access article distributed under the Creative Commons Attribution License, which permits unrestricted use, distribution, and reproduction in any medium, provided the original work is properly cited.

Background. Intestinal parasites are a major source of health problems in developing countries, where socioeconomic, cultural, and environmental conditions contribute in maintaining the biological cycles of various parasites and facilitating their spread. The objective of this study, conducted in Corumbá, Mato Grosso do Sul state, Brazil, was to investigate the occurrence of intestinal parasites in riverside communities in the South Pantanal wetlands and conduct educational interventions focused on health and environmental preservation. Method. In total, 196 stool samples were tested for parasites using the merthiolate-iodine-formaldehyde concentration (MIFC) technique and spontaneous sedimentation and educational activities were carried out. Results. Enteroparasite prevalence was $72 \%$ (65.6-78.2\%; 95\% CI). Of the 141 positive cases, monoparasitism was found in $34.7 \%$, biparasitism in $23 \%$, and polyparasitism in $14.3 \%$. Entamoeba coli was the most frequent protozoan (70.2\%). Among helminths, hookworms were the most prevalent. Enteroparasitosis prevalence did not differ for sex or place of abode but proved higher in individuals older than 10 years. Conclusion. The high positivity rate for enteroparasites found for the communities stems from lack of sanitation and poor personal and environmental hygiene habits, indicating that effective health policies and educational interventions are needed to reduce the current risk levels.

\section{Introduction}

Intestinal parasites are a major debilitating factor, often associated with chronic diarrhea and malnutrition, that can compromise both physical and intellectual development, particularly in younger age groups $[1,2]$.

Intestinal parasites are a major source of health problems in developing countries, where socioeconomic, cultural, and environmental conditions contribute in maintaining the biological cycles of parasites and facilitating their spread $[3,4]$.

Furthermore, the escalation of predatory practices against the environment, compounded by detrimental aspects of political and economic frameworks, collaborates to increase the occurrence of parasitic and other diseases $[5,6]$.
Despite the current status of the Pantanal wetlands as a World Natural Heritage site, owing to its vast biogeographical area and great biodiversity of plant and animal species, many human residents in the region experience difficulties that hamper survival, including the absence of sanitation and healthcare services.

The aim of this study was to investigate the occurrence of enteroparasites among dwellers of three riverside communities in the Pantanal ecosystem, seeking to elucidate key epidemiological factors involved in transmission and perform educational interventions to raise awareness on enteroparasitosis prevention and environmental preservation. 


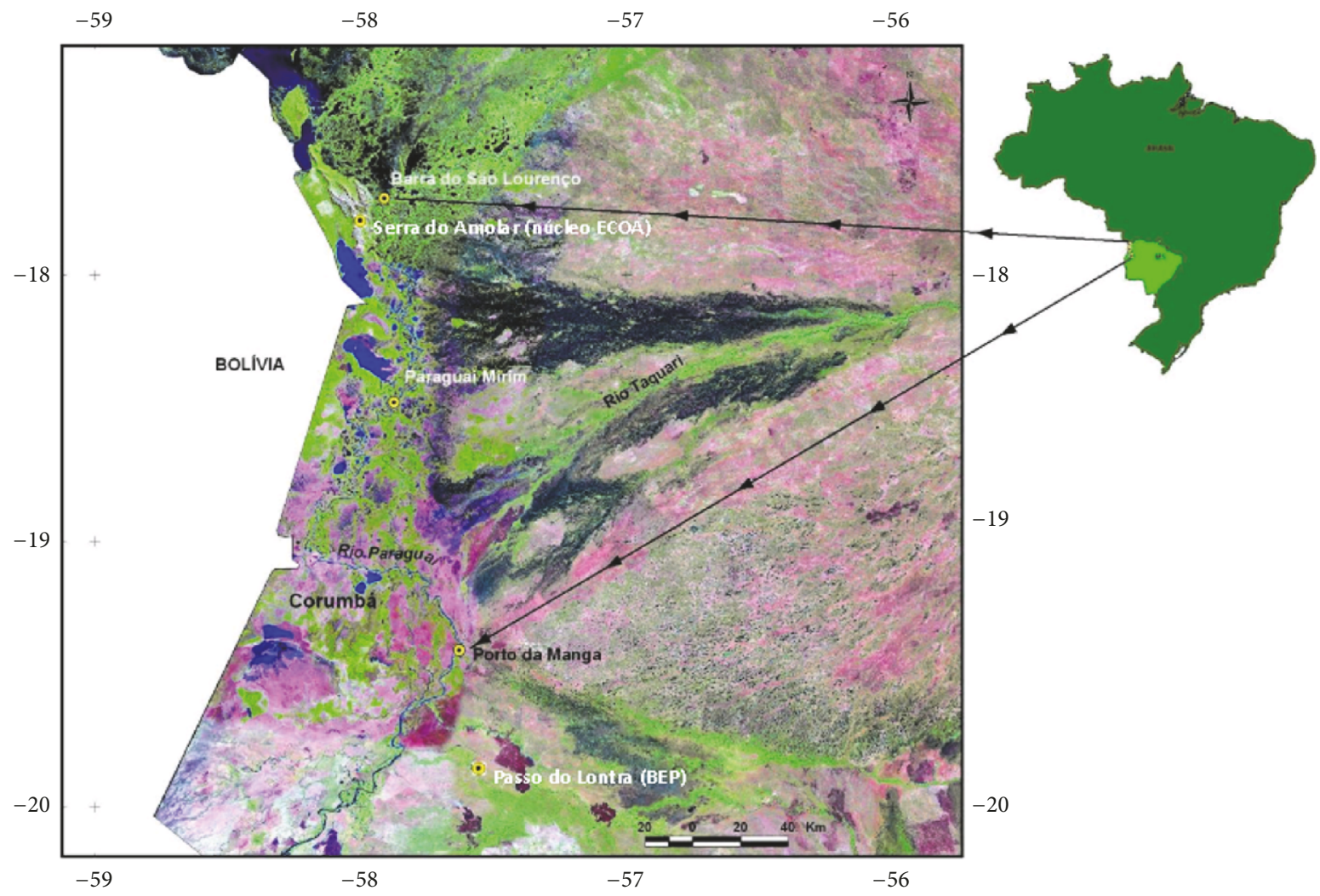

FIGURE 1: Location of the communities investigated. Source: ECOA, 2010.

\section{Materials and Methods}

For this analytical cross-sectional study based on primary data and benchwork research, parasitological stool tests were performed among dwellers of three riverside settlements from July 2008 to July 2009. The communities studied-Barra de São Lourenço, Paraguai Mirim, and Porto da Manga-are located on the Paraguai river in Corumbá county, Mato Grosso do Sul state. Barra de São Lourenço $\left(17^{\circ} 54^{\prime} 0^{\prime \prime} \mathrm{S} ; 57^{\circ} 27^{\prime} 39^{\prime \prime} \mathrm{W}\right)$ and Paraguai Mirim (21k 0454391; UTM 7953009) can only be reached via a $250 \mathrm{~km}$ boat trip from Corumbá, while Porto da Manga $\left(19^{\circ} 15^{\prime} 33.15^{\prime \prime} \mathrm{S}\right.$; $57^{\circ} 14^{\prime} 7.13^{\prime \prime} \mathrm{W}$ ), $385 \mathrm{~km}$ away from Campo Grande (the state capital), is served by the Parque Pantanal state highway (Figure 1).

This study was part of the project entitled Crianças das Águas, Pantanal: Identidade e Cidadania [Children of the Waters, Pantanal: Identity and Empowerment], supported by the Criança Esperança Program (a privately sponsored social mobilization initiative in partnership with the UNESCO). All residents of the area were invited; a total of 196 adults and children (male and female) who voluntarily agreed to participate and provided written informed consent were enrolled in the study. Sample size $(n=196)$ was calculated in the Epi-Info version 7 program, according to the following parameters: population of 400 residents, prevalence of $50 \%$ $( \pm 5 \%)$, and significance level of $5 \%$.

The project was approved by the Universidade Federal de Mato Grosso do Sul (UFMS) Committee for Ethics in
Research in Humans (permit 1612). For the participation of minors (under 18), written approval was obtained from parents or guardians.

Stool samples were collected in merthiolate-iodineformaldehyde solution, stored in suitable containers, and tested at the UFMS Laboratory of Clinical Parasitology using techniques proposed by Blagg et al. [7] (merthiolateiodine-formaldehyde concentration) and Hoffmann et al. [8] (spontaneous sedimentation). Individuals diagnosed with pathogenic parasites were prescribed specific treatment. The educational activities consisted of lectures, a stage play presentation, and individual guidance.

The data were initially treated using descriptive statistics. Chi-squared and chi-squared trend tests were employed to detect associations between variables at a significance level of 5\%. The data were keyed into in Microsoft Excel 2010 spreadsheets (Microsoft, Redmond, WA, USA) and treated using Epi-Info 7.1.1.14 (Centers for Diseases Control and Prevention, Atlanta, GA, USA) and BioEstat 5.3 (Sociedade Mamirauá, Belém, PA, Brazil) software.

\section{Results}

The study comprised 196 subjects ( 83 male, $42.3 \%$; 113 female, $57.7 \%)$. Age ranged from 10 months to 88 years.

Participants reported lack of basic sanitation and garbage collection in the communities (Paraguai Mirim, $n=110$; Barra de São Lourenço, $n=50$; Porto da Manga, $n=$ 
TABLE 1: Distribution of subjects, by presence or absence of enteroparasites, sex, age, and place of abode $(n=196)$.

\begin{tabular}{|c|c|c|c|c|c|c|}
\hline \multirow{3}{*}{ Variable } & \multicolumn{4}{|c|}{ Enteroparasites } & \multirow{3}{*}{$p$} & \multirow{3}{*}{ PR (95\% CI) } \\
\hline & \multicolumn{2}{|c|}{ Present } & \multicolumn{2}{|c|}{ Absent } & & \\
\hline & $N$ & $\%$ & $N$ & $\%$ & & \\
\hline \multicolumn{7}{|l|}{ Sex } \\
\hline Female & 84 & 74.3 & 29 & 25.7 & \multirow{2}{*}{${ }^{(1)} 0.383$} & 1 \\
\hline Male & 57 & 68.7 & 26 & 31.3 & & $1.08(0.90-1.30)$ \\
\hline \multicolumn{7}{|l|}{ Age range (years) } \\
\hline$>40$ & 16 & 94.1 & 1 & 5.9 & \multirow{6}{*}{${ }^{(2)} 0.001$} & 1 \\
\hline $21-40$ & 22 & 78.6 & 6 & 21.4 & & $1.20(0.95-1.50)$ \\
\hline $11-20$ & 23 & 79.3 & 6 & 20.7 & & $1.19(0.95-1.48)$ \\
\hline $6-10$ & 34 & 72.3 & 13 & 27.7 & & $1.30(1.05-1.61)$ \\
\hline$\leq 5$ & 16 & 50.0 & 16 & 50.0 & & $1.88(1.31-2.72)$ \\
\hline No data & 30 & 69.8 & 13 & 30.2 & & - \\
\hline \multicolumn{7}{|l|}{ Place of abode } \\
\hline Paraguai Mirim & 80 & 72.7 & 30 & 27.3 & \multirow{3}{*}{${ }^{(1)} 0.930$} & 1 \\
\hline Barra de São Lourenço & 36 & 72.0 & 14 & 28.0 & & $1.01(0.82-1.24)$ \\
\hline Porto da Manga & 25 & 69.4 & 11 & 30.6 & & $1.05(0.82-1.34)$ \\
\hline
\end{tabular}

PR: prevalence ratio; ${ }^{(1)}$ chi-squared test; ${ }^{(2)}$ chi-square test of trends. Category "no data" was excluded from statistical calculations.

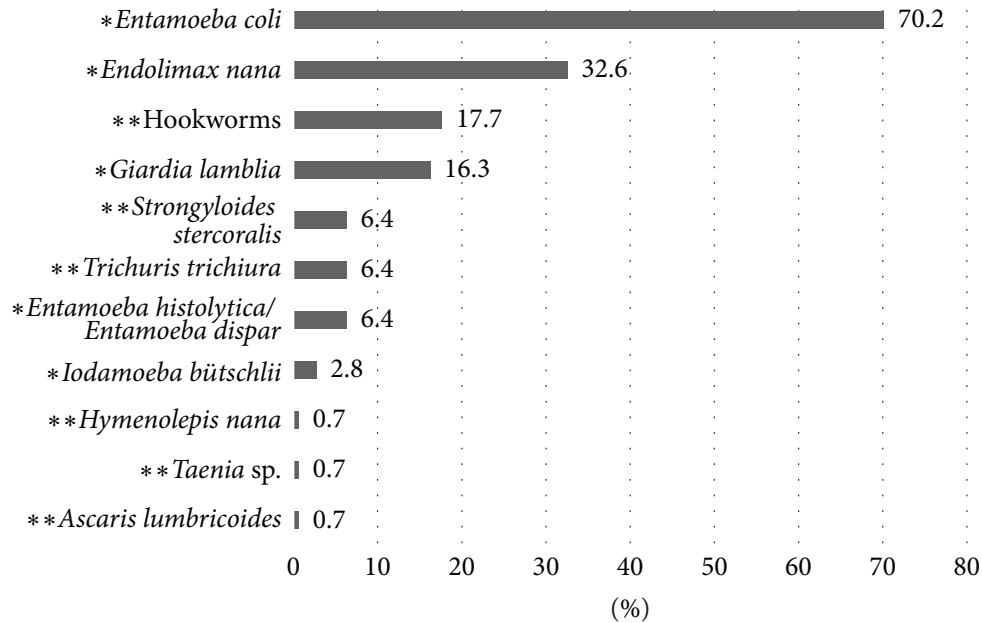

FIGURE 2: Distribution of subjects $(n=141)$, by enteroparasite species detected ( ${ }^{*}$ protozoans; ${ }^{* *}$ helminths).

36). The Paraguai river was their primary water source. The settlements are extremely poor: household income is typically below one Brazilian minimum wage. All garbage is dumped into the river or discarded in the open. Some families use sodium hypochlorite to disinfect water. Houses, made of wood or wattle and daub, are covered with thatch or corrugated fiber cement sheets. Floors are not tiled. There are no bathrooms. Adults work as bait sellers, fishermen, and boat skippers.

No difference was observed between males and females in the prevalence of enteroparasite infection $(p=0.383)$. Prevalence was higher, however, in individuals older than 10 years $(p=0.001)$ (Table 1$)$.

No significant association ( $p=0.930)$ was found between infection prevalence and place of abode (Table 1).
Of the samples investigated, $72 \%$ tested positive for enteroparasites $(65.6-78.2 \%, 95 \% \mathrm{CI})$. Eleven species were identified, comprising $79.7 \%$ protozoa (Giardia lamblia, Entamoeba histolytica/Entamoeba dispar, Entamoeba coli, Endolimax nana, Iodamoeba bütschlii) and 20.3\% helminths Hymenolepis nana, Strongyloides stercoralis, Trichuris trichiura, Ascaris lumbricoides, hookworms, and Taenia sp. (Figure 2).

Among the 141 individuals infected, monoparasitism (48.2\%) prevailed over cases of biparasitism (31.9\%) or polyparasitism (19.9\%). Infection by protozoa predominated.

Entamoeba coli was the most prevalent parasite (70.2\% of the 141 positive cases), followed by Endolimax nana (32.6\%), hookworms (17.7\%), Giardia lamblia (16.3\%), Strongyloides stercoralis (6.4\%), Trichuris trichiura (6.4\%), Entamoeba 
histolytica/Entamoeba dispar (6.4\%), Iodamoeba bütschlii (2.8\%), Hymenolepis nana (0.7\%), Taenia sp. (0.7\%), and Ascaris lumbricoides (0.7\%) (Figure 1).

Seven pathogenic organisms (hookworms, Giardia lamblia, Trichuris trichiura, Strongyloides stercoralis, Ascaris lumbricoides, Taenia sp., Hymenolepis nana), three commensal species (Endolimax nana, Iodamoeba bütschlii, Entamoeba coli) and one undefined (Entamoeba histolytica/Entamoeba dispar complex) were detected.

\section{Discussion}

Distance from urban centers and poor transportation isolate these communities from mainstream society and hamper their access to healthcare services. Unfavorable socioeconomic conditions, lack of sanitation, and educational shortcomings may explain the high prevalence of enteroparasites $[4,9]$. Economically disadvantaged social groups are more prone to a number of diseases, including enteroparasitosis associated with unsanitary conditions that contaminate waterbodies, facilitating the accumulation of waste, including fecal matter from diseased residents and asymptomatic carriers. These environmental conditions promote the proliferation of insects and rodents that act as mechanical vectors for parasites $[10,11]$.

A high prevalence of enteroparasites was also reported in 1994 by Coura et al. [12] for riverside settlements in Amazonas state, with $75.5 \%$ positive cases among 441 tests performed at a $95 \%$ confidence level. More recently, investigating a riverside community in Coari county, Amazonas state, Santos et al. [5] detected $83 \%$ positive cases among children.

Investigating 91 samples from riverside residents in Igarapé Miri county, Pará state, Silva et al. [13] found a 94.5\% positivity rate, with a higher prevalence of enteroparasites in children and adolescents (71.4\%), and a higher frequency of Ascaris lumbricoides (57.14\%) and Trichuris trichiura (41.76\%) helminths. In a previous study [14] of samples from 65 children aged 1-12 years living in the riverside community of San Francisco do Laranjal, in Coari county, an $83.1 \%$ rate of enteroparasite infection was detected.

In the present study, protozoans predominated (79.7\%), particularly Entamoeba coli (70.2\%), a commensal parasite. Its high prevalence is indicative of poor sanitary and socioeconomic conditions, since its fecal-oral transmission also increases the risk of contamination by other pathogens transmitted through the same route [15]. Consumption of untreated water makes riverside settlements more susceptible to waterborne diseases, a feature aggravated by the absence of water supplies other than rivers, into which sewage and other waste flows. These conditions perpetuate the transmission cycles of enteroparasites and other waterborne infective agents [16].

Among helminths, the predominance of hookworms raises concern, given their hematophagous behavior. Particularly in children, infection can lead to iron-deficiency anemia and hypoproteinemia, with subsequent edema, atrophy of the intestinal mucosa, and decreased absorption [3, 17]. A high prevalence of hookworms has been reported for other riverside populations. Proximity to water, combined with a humid, warm climate, sandy soil, and poor sanitation, creates favorable conditions for larval development and persistence in the environment $[18,19]$.

Despite a predominance of monoparasitism, cases of polyparasitic infection require attention, given their high probability of including pathogenic species.

No significant differences in infection prevalence were found for place of abode or sex; this result was confirmed by some studies [20]. The high positivity rate for enteroparasites, whether pathogenic or commensal reflects the exposure of these communities to soil and water contamination and their poor hygiene habits, demonstrating that transmission and maintenance of parasitic infections are part of an interactive process involving infective agent, environment, and susceptible host.

\section{Conclusion}

The high positivity rate for enteroparasites detected in these riverside settlements in the South Pantanal wetlands reflects the absence of basic sanitation and poor personal and environmental hygiene habits.

This study, the first to investigate the occurrence of enteroparasitosis in riverside communities in this region, revealed the need for the implementation of effective measures in environmental and health education, as well as investment in sanitation infrastructure, to improve the quality of life of this population.

\section{Ethical Approval}

The project was approved by the Universidade Federal de Mato Grosso do Sul (UFMS) Committee for Ethics in Research in Humans: 438.257-28/10/2013.

\section{Conflicts of Interest}

The authors declare that there are no conflicts of interest.

\section{Authors' Contributions}

Maria Elizabeth Cavalheiros Dorval participated in writing and revision of the manuscript and gave final approval of the version to be published. Patrícia Vieira da Silva participated in analysis and interpretation of data and writing of the manuscript. Lucimare dos Santos Maciel participated in analysis and interpretation of data and writing of the manuscript. Ludiele Souza Castro, Paula Murat, Minoru German Higa Junior, Patrícia Zerlotti, and Ana Rita Coimbra Motta Castro participated in data collection and writing of the manuscript. Elenir Rose Jardim Cury Pontes participated in analysis and interpretation of data.

\section{Acknowledgments}

This study was financed by the Ecology and Action (ECOA) NGO. The authors wish to acknowledge the Ecology and Action (ECOA) NGO and the Universidade Federal de 
Mato Grosso do Sul for their partnership and logistical support. Thanks are also extended to the members of the riverside communities investigated, for their participation and hospitality.

\section{References}

[1] A. F. Hurtado-Guerrero, F. H. Alencar, and J. C. HurtadoGuerrero, "Ocorrência de enteroparasitas na população geronte de Nova Olinda do Norte Amazonas, Brasil," Acta Amazonica, vol. 35, no. 4, pp. 487-490, 2005.

[2] H. Nahrevanian, M. Assmar, S. M. Zahraei, M. Mafi, H. M. Asl, and F. S. Ghasemi, "Sporozoan protozoa and enteroparasites in the gastroenteritic patients referring to the healthcare centers of seven provinces of Iran," International Journal of Enteric Pathogens, vol. 3, no. 3, article e27087, 2015.

[3] L. Rey, "Um século de experiência no controle da ancilostomíase," Journal of the Brazilian Society of Tropical Medicine, vol. 34, no. 1, pp. 61-67, 2001.

[4] P. Okyay, S. Ertug, B. Gultekin, O. Onen, and E. Beser, "Intestinal parasites prevalence and related factors in school children, a western city sample-Turkey," BMC Public Health, vol. 4,2004

[5] F. S. Santos, A. S. Gama, A. B. Fernandes, J. D. Reis Junior, and J. Guimarães, "Prevalência de enteroparasitismo em crianças de comunidades ribeirinhas do Município de Coari, no médio Solimões, Amazonas, Brasil," Revista Pan-Amazônica de Saúde, vol. 1, no. 4, pp. 23-28, 2010.

[6] L. F. Nimri and M. Meqdam, "Enteropathogens associated with cases gastroenteritis in a rural population in Jordan," Clinical Microbiology and Infection, vol. 10, no. 7, pp. 634-639, 2004.

[7] W. Blagg, E. L. Schloegel, and N. S. Mansur, "A new concentration technic for the demonstration of protozoa and helminth eggs in feces," American Journal of Tropical Medicine and Hygiene, vol. 4, pp. 23-28, 1955.

[8] W. A. Hoffmann, J. A. Pons, and J. L. Janer, "Sedimentation concentration method in schistosomiasis mansoni," Puerto Rico Journal of Public Health, vol. 9, pp. 283-298, 1934.

[9] Y. B. Wang, Y. Xu, X. L. Kong, B. G. Zhang, B. u. XQ, C. L. Zhao et al., "Survey of intestinal parasitic infections and related knowledge and behavior of residents in jiaodong area of shandong province," Zhongguo Xue Xi Chong Bing Fang Zhi Za Zh, vol. 26, no. 4, pp. 376-381, 2014.

[10] K. M. Ludwig, F. Frei, F. A. Filho, and J. T. Ribeiro-Paes, "Correlação entre condições de saneamento básico e parasitoses intestinais na população de Assis, Estado de São Paulo," Journal of the Brazilian Society of Tropical Medicine, vol. 32, no. 5, pp. 547-555, 1999.

[11] R. L. Puleston, C. M. Mallaghan, D. E. Modha et al., "The first recorded outbreak of cryptosporidiosis due to Cryptosporidium cuniculus (formerly rabbit genotype), following a water quality incident," Journal of Water and Health, vol. 12, no. 1, pp. 41-50, 2014.

[12] J. R. Coura, H. P. F. Willcox, A. d. M. Tavares, D. D. de Paiva, O. Fernandes, É. L. J. C. Rada et al., "Aspectos epidemiológicos, sociais e sanitários de uma área do Rio Negro, estado do Amazonas, com especial referência às parasitoses intestinais e à infecção chagásica," Cadernos de Saúde Pública, vol. 10, supplement 2, pp. 327-336, 1994.

[13] A. M. Silva, R. C. Bouth, K. S. Costa et al., "Ocorrência de enteroparasitoses em comunidades ribeirinhas do Município de
Igarapé Miri, Estado do Pará, Brasil," Revista Pan-Amazônica de Saúde, vol. 5, no. 4, pp. 45-51, 2014.

[14] E. F. Silva, V. B. C. Silva, and F. L. C. Freitas, "Parasitoses intestinais em crianças residentes na comunidade ribeirinha São Francisco do Laranjal, município de Coari, Estado do Amazonas, Brasil," Revista de Patologia Tropical, vol. 41, no. 1, pp. 97-101, 2012.

[15] E. D. Moreira Jr., V. B. Nassri, R. S. Santos et al., "Association of Helicobacter pylori infection and giardiasis: results from a study of surrogate markers for fecal exposure among children," World Journal of Gastroenterology, vol. 11, no. 18, pp. 2759-2763, 2005.

[16] C. M. Salazar and G. S. Flores, "Carga parasitaria en aguas de regadío de la zona agrícola Chacra cerro alto, Lima- Perú," The Biologist, vol. 10, no. 2, 2012.

[17] A. Kousha, S. Hakimi, E. Fallah, I. Nokhahi, S. Sarafraz, and A. Shahnami, "Prevalence of intestinal parasites among symptomless primary school children attending urban health centers, Tabriz," Medical Journal of Tabriz University, vol. 33, no. 3, pp. 58-62, 2011.

[18] L. C. Dias, J. D. Filho, M. G. Paes, A. N. Farias, and J. C. Aguiar, "Prevalência de parasitas intestinais em habitantes do Rio Negro, Estado do Amazonas, Brasil," Acta Amazonica, vol. 12, no. 1, pp. 65-70, 1982.

[19] D. Neves, Parasitologia Humana, Atheneu, São Paulo, Brazil, 11th edition, 2005.

[20] S. Seyrafian, N. Pestehchian, M. Kerdegari, H. A. Yousefi, and B. Bastani, "Prevalence rate of Cryptosporidium infection in hemodialysis patients in Iran," Hemodialysis International, vol. 10, no. 4, pp. 375-379, 2006. 


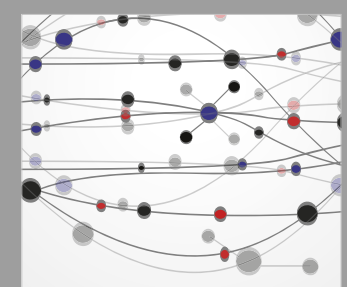

The Scientific World Journal
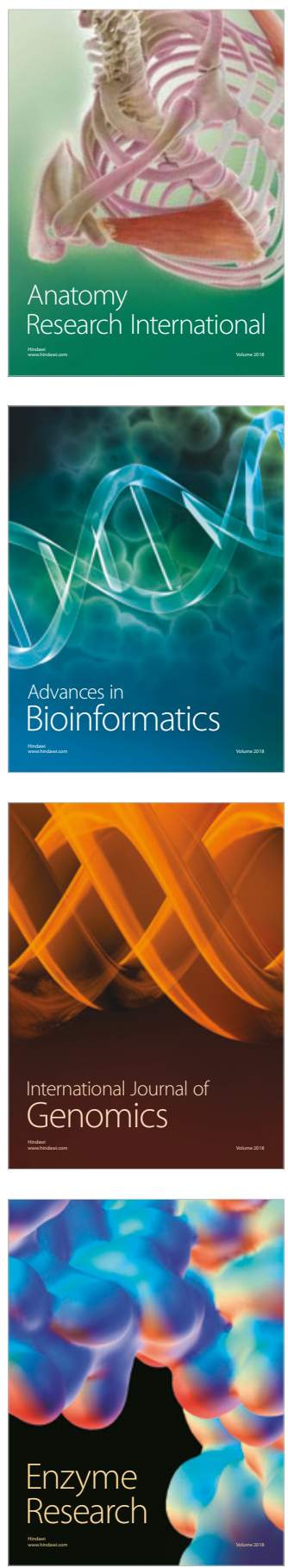
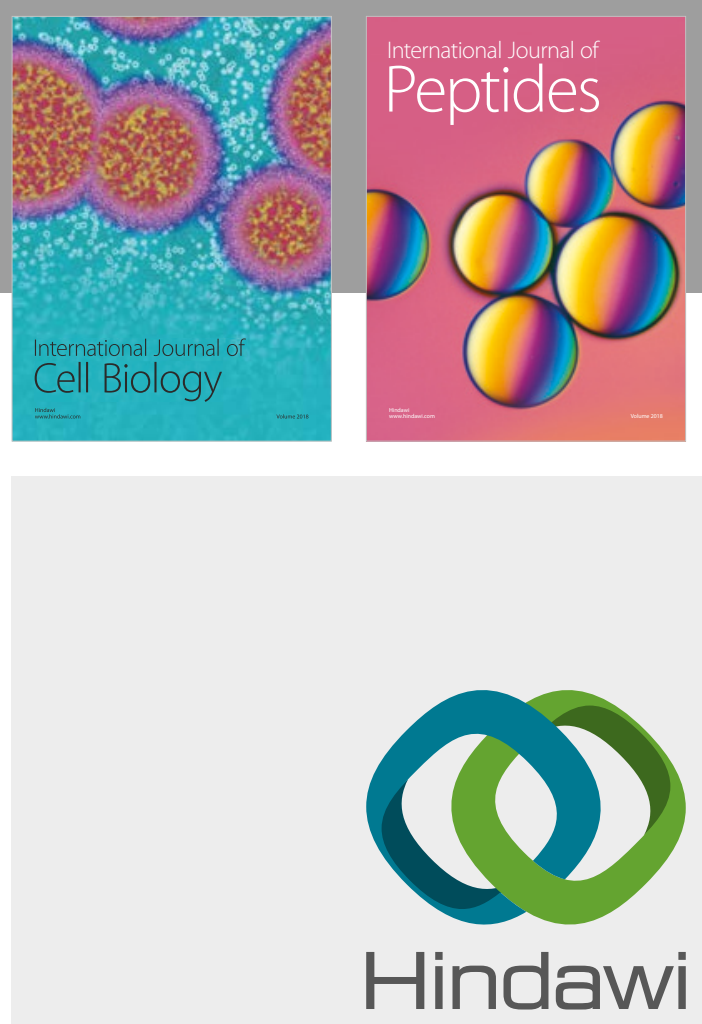

Submit your manuscripts at

www.hindawi.com
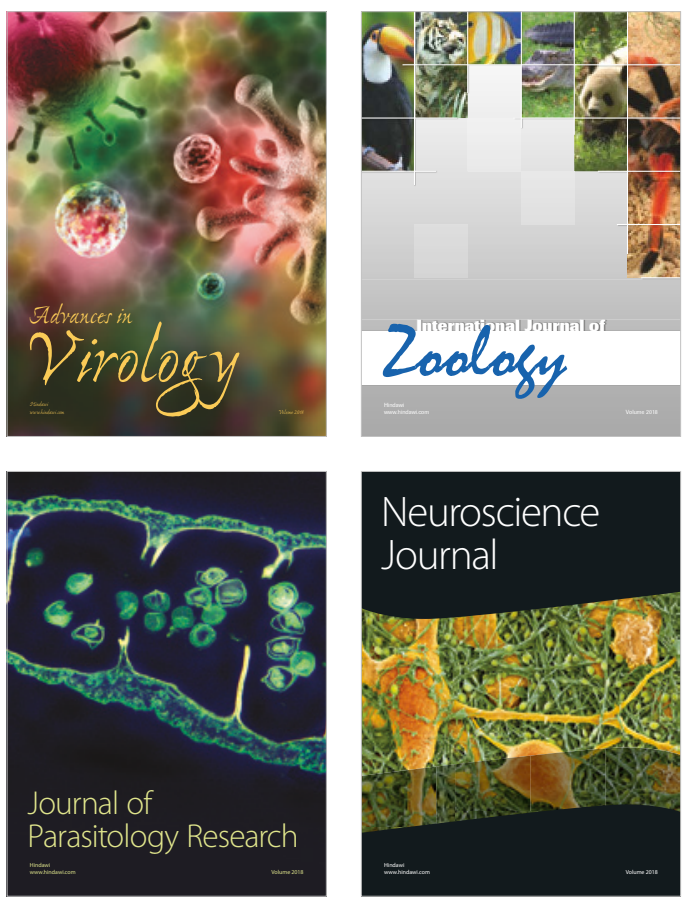
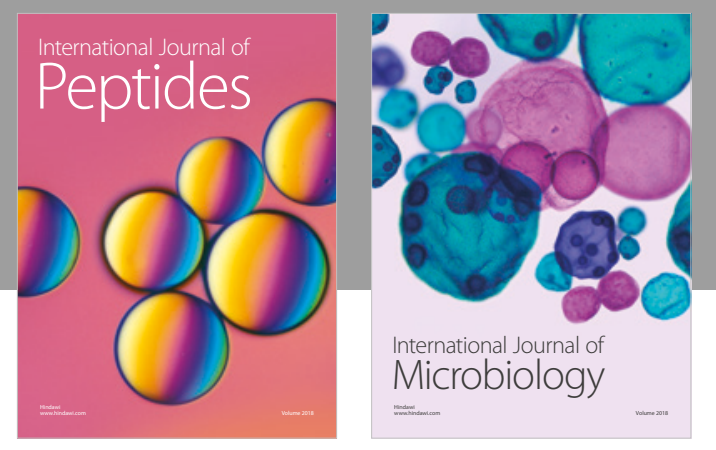

nternational Journal of Microbiology
Journal of
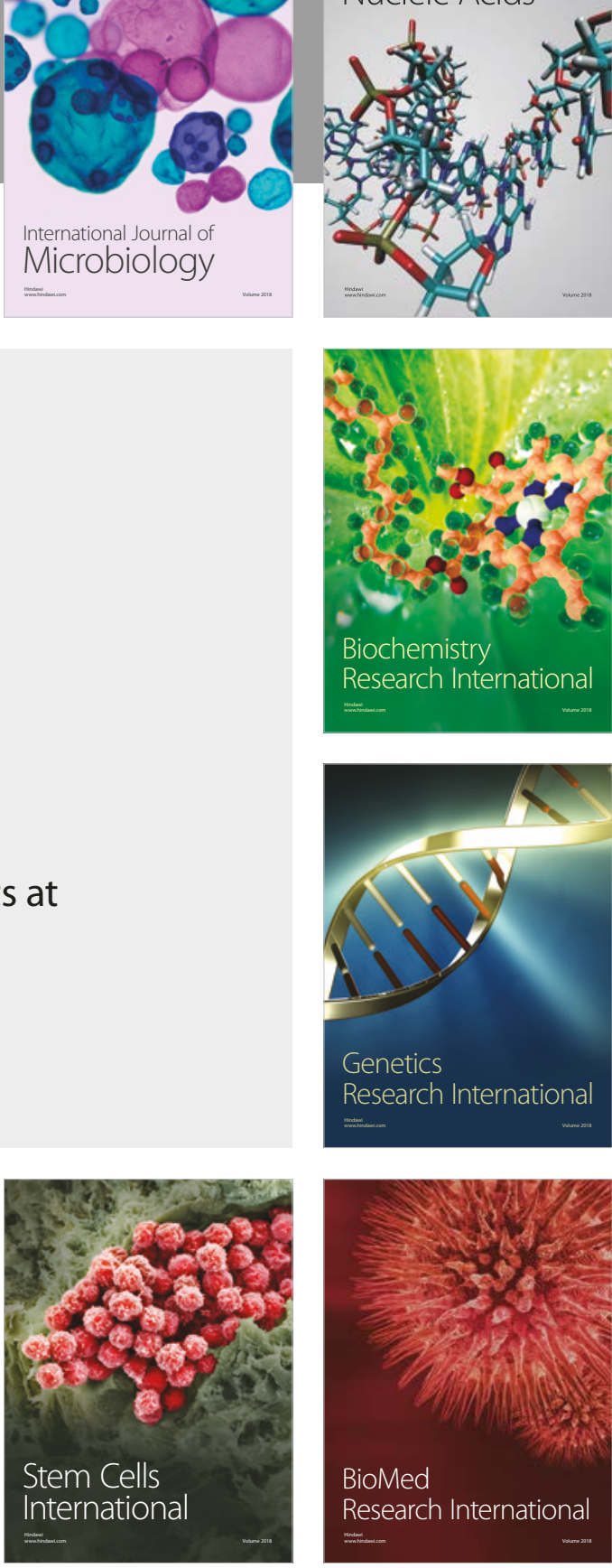
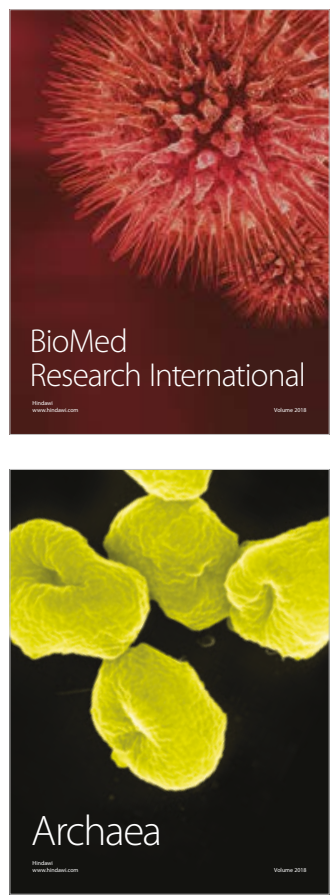